\title{
ARCHAEOLOGY
}

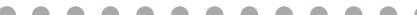

\begin{abstract}
Known since the beginning of the 20th century, the circular frontier watchtower from Porolissum-Poiana Mogrădanilor was the subject of two archaeological excavations that took place in 1970 and 1997, made by Nicolae Gudea and Alexandru V. Matei, in a larger research frame of the North-Wester frontier of Dacia Porolissensis. Resuming the older accounts of A. Buday, A. Radnóti, I. Ferenczi and N. Gudea, Alexandru V. Matei took a step forward and excavated this particular watchtower. The purpose of this study is to capitalize his archaeological documentation resulted from the excavation. Unfortunately, the archaeological material was not identified, except for a drawing of two signacula of legio XIII Gemina. More than that, Alexandru V. Matei identified the building technique of the linear fortification that lies in front of the watchtower. The excavation journal is also missing, the only available info being a plan of the structure and a profile. Connecting this data, we tried to create a coherent image of this particular minor fortification. In order to fulfil it, several geostatistical analyses and a new topographical survey were used.
\end{abstract}

Keywords: Roman frontier, Dacia Porolissensis, frontier watchtower, military stamps, GIS analyses.

\section{Horațiu Cociș}

Zalău County Museum of History and Art hcocis12@gmail.com

DOI: $10.14795 /$ j.v6i1.366

ISSN 2360 - 266X

ISSN-L 2360 - 266X

\section{ARCHAEOLOGICAL BACKGROUND.} represented in the past decades a research field that produced an impressive amount of studies with various topics, from field surveys ${ }^{1}$, aerial photos/scanning and geophysical surveys ${ }^{2}$ to archaeological excavation ${ }^{3}$ and frontier (functionality) interpretations ${ }^{4}$ with direct focus on the minor limes installations. The watchtower discussed here took part in a wider research carried out during the past century. However, the only

\footnotetext{
For example TORMA 1880; TÉGLÁS 1906 393-410; TÉGLÁS 1907, 565-580; BUDAY 1912, 103 118; BUDAY 1914, 95-105; FERENCZI 1941, 189-214; FERENCZI 1967, 143-162; MATEI/LAKO 1979, 121-135; MATEI 1996, 63-73; MATEI 2007, 250-269; MARCU/CUPCEA 2013, 569-589.

2 For example RADNÓTI 1945, 137-168; SCURTU 1997, 361-372; SCURTU 2003, 257-279; FRANZEN/MATEI/MARCU 2007, 161-177; OPREANU/LĂZĂRESCU/ȘTEFAN 2013, 83-106; OPREANU/LĂZĂRESCU/ȘTEFAN 2013a, 509-524.OPREANU et alii; 2014, 71-86; ROMAN et alii 2016, 238-261; OPREANU/LĂZĂRESCU 2016, 49-115.

3 For example FINÁY 1904 9-15; DAICOVICIU 1935, 240-256; FERENCZI 1941, 189-214; MOGA 1950, 131-135; GUDEA 1985, 143-218; GUDEA 1997; MATEI 2005, 293-311; MATEI 2007, 250-269.

4 For example TORMA 1880; BUDAY 1912, 103-118; FABRICIUS 1926, 642; FERENCZI 1968, 75-98; FERENCZI 1971; 599-625; GUDEA 2000, 209-230; See the detailed discussion in COCIȘ 2016, 41-75.
} 
one who truly excavated this structure was the former archaeologist Alexandru V. Matei.

The first possible account of the watchtower from Poiana Moigrădanilor or La Maje was made by the Hungarian scholar Buday Ápád, in $1912 .^{5}$ Later, în 1945, when Radnóti Aladár with the help of the Hungarian aviation made the first batch of aerial photos on the North-Western frontier area, ${ }^{6}$ the structure was visible on one of them (Plate II a), ${ }^{7}$ together with the linear fortification and the aqueductus from the specified area. ${ }^{8}$ Integrated is his large surveys, ${ }^{9}$ the next mention of the tower was made by I. Ferenczi in $1967 .^{10}$

The first systematic archaeological research carried out within the chain line of watchtowers from the Meseș Muntains and Porolissum areas was the contribution of $\mathrm{N}$. Gudea. Excavating almost 70 watchtowers, ${ }^{11}$ he

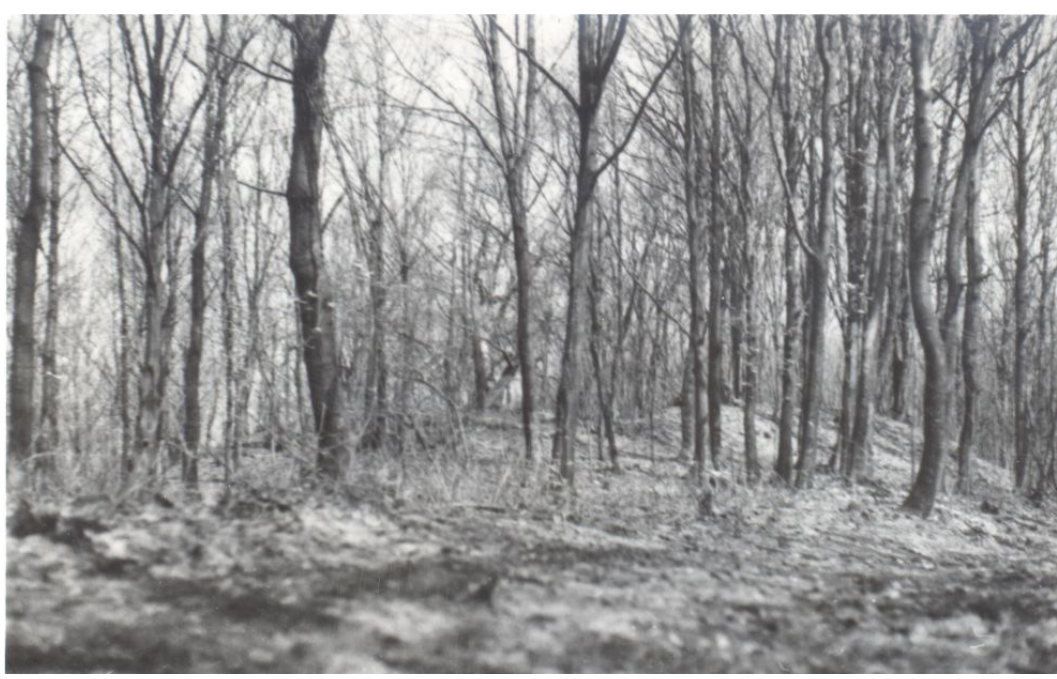

Fig. 1. The watcthower from Poiana Moigrădanilor = La Maje in 1976 (ZCMHA archive).

In 1997, after the field survey undertook in this area, ${ }^{18}$ he decided to excavate the tower alltogether with the fossavallum system that lies in front of it. ${ }^{19}$ In order to do that, him and his team performed a trench of $45 \times 2$ m orientated NW-SE, overlapping the structure of the watchtower and the linear fortification (Plate III).

\section{- The watchtower}

The structure is located on a dominant emplacement at the selvage, being integrated within the linear fortification that goes from Poiana Moigrădanilor to the custom house of Porolissum. (Plate I). The watchtower belongs to the circular type, having a diameter of $7.5 \mathrm{~m} .{ }^{20}$ It is built in the opus incertum technique; the raw material used is the local limestone, some of the stones being faceted. The width of the wall varies between $1-1.3 \mathrm{~m}$ with 7 observable layers of stones, on a height of $1.3 \mathrm{~m}$. The foundation has a height of $30 \mathrm{~cm}$.

The stratigraphic sequence inside the tower reveals several interesting aspects. Under the top soil and the demolition layer (dark soil mixed with gravel and stones) a sandy yellowish soil was observed, belonging probably to the building process of the foundation. The layer was observed also outside the tower. In this layer, a dark feature was found, belonging as the ground plan reveals to a wooden beam of $1.6 \times 32 \mathrm{~cm}$ used probably in the building process of the floor. Under this layer, another brownish layer mixed with smashed limestone appeared, most probably a leveling process. Near the walls, inside and outside the tower, two post holes and a wooden bean appeared. Based on their depth and relation with the stone structure, we advance the hypothesis according to witch these contexts are belonging to a timber phase of the watchtower.

\footnotetext{
18 The field surveys were carried out starting with 1976; COCIȘ 2016, 48.

19 For this segment see COCIȘ 2016, 41-54, Pl. XIV.

20 See direct analogies of circular watchtower at Cornu Vlașinului I (TORMA 1880, 61; BUDAY 1912, 108; TIR L34, 119; GUDEA 1985, 164-165; GUDEA 1997, 45-46); Dealu Mare (BUDAY 1912, 110; GUDEA 1985, 166; GUDEA 1997, 48-49); Șumanda (TORMA 1880, 74; BUDAY 1912, 111; GUDEA 1985, 166-167; GUDEA 1997, 50-51); Dealu Cozli (TORMA 1880, 73; FERENCZI 1967, 147; GUDEA 1985, 165; GUDEA 1997, 47-48), Salhiger (GUDEA 1985 165-166; GUDEA 1997, 48); Coasta Ciungii I (FERENCZI 1968, 80; GUDEA 1985, 171); see also two recently studied circular watchtowers in COCIȘ/ BĂCUEȚ-CRIȘAN/BEJINARIU 2018, fortcoming; COCIȘ 25-21,2018.
} 
The defensive ditch was identified in the NW and (probably in the) SE side of the trench at a variable distance of 3-6 m; its structure is not uniform, the opening of the ditch varying from 1.2-0.9 m, with a depth between 1.2-0.2 m.

Based on the CBM identified within the excavation one can conclude the fact that the structure of the watchtower was built using a foundation of limestone, at least the first level being constructed using a such technique. The large number of bricks, tegulae and imbrices identified on the spot indicates a mixed building technique for the elevation and a rooftop covered with the mentioned material. ${ }^{21}$ Regarding the timber phase, the reduced amount of data is for now an impediment in understanding this early context. ${ }^{22}$

\section{- The linear fortification.}

Set $6 \mathrm{~m}$ North-West of the tower, the linear fortification composed of a vallum, a palisade and two ditches was included in the trench. The stratigraphic sequence recorded by Alexandru V. Matei reveals both the inner structure of the linear features and the chronological relation with the watchtower. As we can read on the profile and the ground plan (Plate IV), wooden beams placed on the virgin soil were used to strengthen the vallum; ${ }^{23}$ five such beams were uncovered (Plate VII, a-c).

The chronological relation with the watchtower is given by the next context. A leveling layer (dark brownish loam mixed with small stones) is overlapping the wooden beams but also the defensive ditch of the watchtower. We conclude that at least on this side the defensive ditch of the watchtower is disaffected by the palisade construction; another theory, yet with a high degree of speculation, is that the defensive ditch belonged to the timber phase of the watchtower, being disaffected by the palisade, contemporary action with the making of the stone structure.

The vallum core, a grey loam layer mixed with gravel, is overlapped by a consistent layer of charcoal, the remaining marks of a timber palisade. All these elements are covered by a thick demolition layer containing also bricks and stones from the stone watchtower. As it is normal, the palisade is accompanied by a defensive ditch, only in this case we have two of them belonging to different phases. The defensive ditch from the first phase is located $2.3 \mathrm{~m}$ in front of the palisade. It has an opening of $2.2 \mathrm{~m}$ and a $U$-shaped profile with a depth of $1.8 \mathrm{~m}$. Based on the stratigraphy, it has a multiple fill consisting (from the bottom to the top) of a dark soil, dark brown soil and an open grey soil.

Cutting the first defensive ditch and being interposed between it and the palisade, a second ditch was identified, belonging to a subsequent phase. It has a larger opening of $3.4 \mathrm{~m}$ and a $U$-shaped profile with depth of $1.3 \mathrm{~m}$. The fill is composed of open grey soil. According to the available date, the archaeological situation of a double phase defensive ditch is quite common in the North-Western frontier area ${ }^{24}$ and Porolissum, ${ }^{25}$ due to the fact that the frontiers are

\footnotetext{
${ }^{21}$ See COCIȘ/BĂCUEȚ-CRIȘNA/BEJINARIU 2018, forthcoming.

22 COCIȘ 2018, 23.

23 Similar situation at the frontier system from Viținal Hill (MATEI 2007, 253, 264, PL. VII)

24 See COCIȘ 2016, 65, Pl. XI.

25 See MATEI 1996, 73, Fig. 5.b; the digitalized profiles in COCIȘ 2016, 70, Pl. XVI.
}

developing in time, ${ }^{26}$ as we can see in several other frontier areas such Germania Superior ${ }^{27}$ or Britannia. ${ }^{28}$

\section{- The military stamps.}

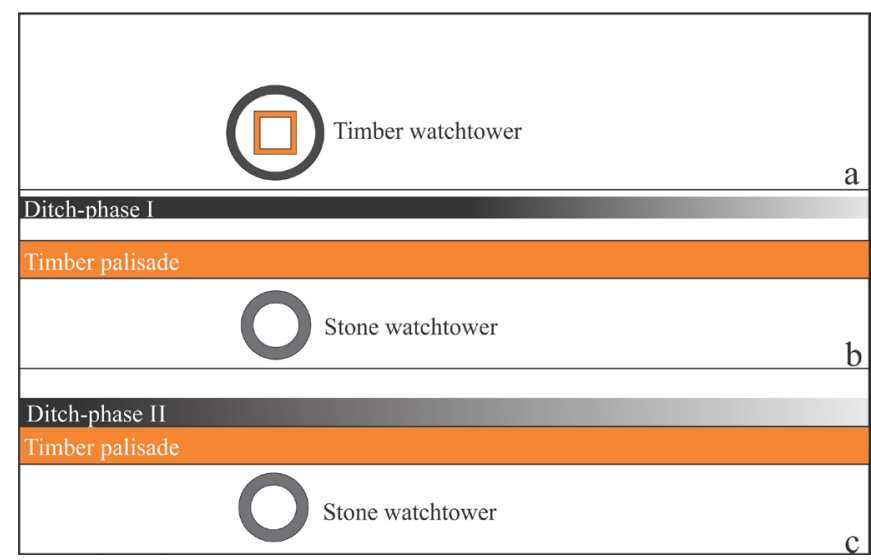

Fig. 2. Chronological layers of the frontier system from Poiana Moigrădanilor based on Matei's documentation: $a$-timber phase, $b$-stone phase, palisade with defensive ditch, phase 1 and c- stone phase, palisade with defensive ditch, phase 2 .

We mentioned already that the only archaeological material recorded by Alexandru V. Matei were two military stamps of legio XIII Gemina ${ }^{29}$. Unfortunately he did not mention if they are bricks or tiles; instead of that, the find spot within the trench is recorded quite accurate: the

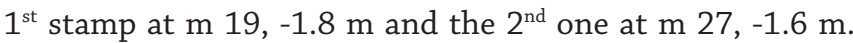
Correlating the info with the ground plan and the profile, we observed that the find spot of the stamps is basically under the levelling layer of the stone phase, near the postholes and the wooden beam; this particular aspect place them in an early archaeological context-the timber phase of the watchtower.

In support of this hypothesis we bring into discussion the analogies (military stamps) found within the auxiliary fort from Porolissum-Pomet locate only $2.4 \mathrm{~km}$ East of the watchtower. ${ }^{30}$ There are two main types of signacula belonging to the $13^{\text {th }}$ legion found at Porolissum, ${ }^{31}$ the stamps from the watchtower being framed within the first category $^{32}$ (Plate VIII).

The presence of the $13^{\text {th }}$ legion is attested throughout the existence of the province Dacia, ${ }^{33}$ the mentioned stamps

\footnotetext{
6 BREEZE 2011, 5.

BAATZ 1976, 9-13;

BREEZE/DOBSON 1970, 109-121; BREEZE 2011, 81.

The stamps were previously published in a recent study concerning the military stamps from the frontier watchtowers of Dacia Porolissensis. The description of the stamps in COCIȘ 2018a, 403: Both of the stamps have a rectangular signaculum, most probably the letters from the cartridge are in positive and the name of the legion is flanked by ansae in relief. The first stamp has two horizontal hastae, above and below XIII. The dimension of the stamp are $10.3 \times 2.8 \mathrm{~cm}$ and the letters varies between $1.4-1.7 \mathrm{~cm}$ (fragmented)... The second stamp is very similar with the first one. This type has an $L$ with an oblique bar in lower side. Also, the XIII has only a hasta on the upper side. The dimensions of the stamp are $10.2 \times 2.8 \mathrm{~cm}$ and the letters reach $1.4-1.7 \mathrm{~cm}$

30 COCIS 2018a, 405.

PISO/DEAC 2016, 31-33.

Type 1: PISO/DEAC 2016, 31-32, IX/1-2.

RITTERLING 1925, 1716-1728; MOGA 1985, passim; GUDEA 1997a, 107-108; PISO 2000, 220-224; PISO 2005, 422-427.
} 
being quite similar with the types found at Apulum. ${ }^{34}$ Based on the archaeological evidence found in the auxiliary fort of Porolissum-Pomet has been advance the hypothesis that a vexillatio was garrisoned here in the reign of Trajan and Hadrian, in the early phases of the fort ${ }^{35}$ (and the frontier). In our opinion, the stamps identified in an early context of the watchtower strengthens the fact that legio XIII Gemina is actively involved in the building process of the frontier ${ }^{36}$ in the time of the aforementioned emperors; ${ }^{37}$ we must also consider that the linear fortifications setup on large areas, in the frontier zones, is a Hadrianic concept. ${ }^{38}$

\section{-Topographic survey and GIS analyses.}

A necessity of every excavation is the topographic survey of the research area altogether with the excavated trenches, contexts and small finds. Unfortunately, in the late 90s this methodology was no a trend. Due to this fact we pursued a brand new topographic survey of the visible ruins and the archaeological trench in order to have a clear and correct image of the site situation. ${ }^{39}$ The date was processed being created a Digital Terrain Model (DTM) with a resolution of $0.5 \mathrm{~m}$, overlapped by the georeferenced archaeological ground plan (Plate III).

Already a classic method, ${ }^{40}$ we applied as the last part of the study, analyses from the geostatistic sphere: Cumulative Viewshed Anlayses (CVA), Line of Sight profiles (LOS) and Least Cost Path (LCP) in order to observe the intervisibility pattern of the watchtower with the neighboring installations, the visible area from the site and the shortest ways to reach it from other sites.

From the visibility point of interest, ${ }^{41}$ the covered area is quite reduced, the visual field being orientated towards the province as in several cases from this area. ${ }^{42}$ The intervisibility pattern is also quite limited: ${ }^{43}$ direct line of sight with the auxiliary fort from Porolissum-Pomet, the auxiliary fort from Porolissum-Citera, the watchtower from Ferice Hill, the custom house and the watchtower from Dealu Mare. Based on the SRTM evaluation, it seems that the access ways follows a well know pattern, the most accessible routes toward the tower being mainly the ridge roads ${ }^{44}$ (Plate IX).

We finish the pages concerning this particular watchtower by adding to the general view of the frontier several new aspects regarding the chronology and the functionality of the limes in this area. The reduced but ${ }_{34} \mathrm{PISO} / \mathrm{DEAC} 2016,31$.

35 PISO 2000. 200-201; MARCU 2009, 99 with older bibliography; PISO/ DEAC 2016, 31

${ }_{36}$ The epigraphic presence of the legion in another early context was attested at the auxiliary fort from Tihău-Cetate (PROTASE 1960, 385, fig. 24; WOLLMANN/BOT 1974, 27-28, fig. 54; GUDEA/LUCĂCEL 1975, 27-28, nr. 54, fig. 54; PROTASE 1994, 94, fig. 10; PROTASE 1995, 324; AÉ 1994, 484; ILD 760; text after ILD 760: Vexillat(io) / leg(ionis) XIII / Gem(inae).

$37 \mathrm{PISO} / \mathrm{DEAC} 2016,31$

38 See mainly WHITTAKER 1994, 60-98; BREEZE 2012, 55-91.

${ }_{39}$ The topographical points have been achieved using a GPS RTK Hi-Target V90 Plus; $\odot$ Zalău County Museum of History and Art.

40 See mainly GUDEA 1979, 63-87; GUDEA 1985, 197, fig. 15; GUDEA 1997, 102, fig. 10, 113, fig. 21; 126, fig. 34; MARCU/CUPCEA 2013, passim; LĂZĂRESCU/BILAȘCO/VESCAN 2016, 275-304; TEODOR 2016, 67-96; COCIȘ 2018b, 76-74, Pl. X-XII.

${ }^{41}$ Parameters: SRTM $1.5 \mathrm{arc} / \mathrm{sec}$; T. e $=8 \mathrm{~m}, \mathrm{R} . \mathrm{e}=2 \mathrm{~m}, \mathrm{R}=10 \mathrm{~km}$

42 COCIȘ/BĂCUET⿱-CRIȘAN/BEJINARIU 2018, forthcoming.

43 Parameters: SRTM $1.5 \mathrm{arc} / \mathrm{sec}$; T. e $=8 \mathrm{~m}$, R. e $=8 \mathrm{~m}$.

44 See the discussion in COCIȘ 2018b, passim. important data coming from this archaeological excavation could set a starting point for a larger research focused on the early phases of the minor installations from Dacia Porolissensis.

\section{REFERENCES:}

BAATZ 1976

Baatz, D., Die Wachtürme am Limes (Aalen: Limesmuseum).

\section{BREEZE/DOBSON 1970}

Breeze, D./Dobson, B., The development of the mural frontier in Britain from Hadrian to Caracalla, Society of Antiquaries of Scotland 102, 109-121.

\section{BREEZE 2011}

Breeze, D., Roman frontier in their landscape settings (Newcastle upon Tyne).

\section{BREEZE 2012}

Breeze, D., The Frontiers of Imperial Rome (Barnsley).

\section{BUDAY 1912}

Buday, A., Vannak-a limes maradvániok a Meszesen?, Dolgozatok az Erdelyi Muzeum Erem-es Regisegtarabol 3, 103-118.

\section{BUDAY 1914}

Buday, A., Limesmaradványok Porolissum környékén, Dolgozatok az Erdelyi Muzeum Erem- es Regisegtarabol 5, 95-105.

\section{COCIS 2016}

Cociș, H., Linear Fortifications on the North-Western Frontier of Dacia Porolissensis. An Overview. In: V. Bârcă (ed.), Orbis Romanus and Barbaricum. The Barbarians around the Province of Dacia and Their Relations with the Roman Empire (Cluj-Napoca: Mega), 41-75.

\section{COCIȘ 2018}

Cociș, H., Turnul de supraveghere roman de la MirșidFăjiște (comuna Mirșid, jud. Sălaj), Buletinul LIMES 4, 2125.

\section{COCIȘ 2018a}

Cociș, H., Some Considerations on the Brick and Tiles Stamps from the Frontier Watchtowers of Dacia Porolissensis. In: S. Forțiu (ed.), Arheovest VI. Interdisciplinaritate în arheologie. In memoriam Marian Gumă (Szeged: JATEPress), 399-415.

\section{COCIȘ 2018b}

Cociș, H., The Fortlets on the Frontier of Dacia Porolissensis: Structures, Landscape, Functionality, Studia Universitatis Babes Bolyai 63, 1, 34-77.

DAICOVICIU 1935

Daicoviciu, C., Dacica. În jurul unor probleme din Dacia romană, Anuarul Institutului de Studii Clasice 2, 1933-1935 (1935), 240-256.

\section{FABRICIUS 1926}

Fabricius, E., Limes, Realencyclopadie der Classichen Altertumswissenschaft 13, 642.

\section{FERENCZI 1941}

Ferenczi, I., Régészeti megfigyelések a limes dacicus északnyugati szakaszán, Erdelyi Muzeum 41, 189-214.

\section{FERENCZI 1959}

Ferenczi, I., Contribuții la problema limesului de vest al Daciei (I), Studii și Cercetări de Istorie Veche 10, 337-354.

\section{FERENCZI 1967}

Ferenczi I., Die erforschung des römischen Limes auf den Höhen des Meseș-Gebirges. (Ein Vorbericht), Dacia N. S. XI, 143-162.

\section{FERENCZI 1968}

Ferenczi, I., Observații cu privire la sistemul și caracterul așa-zisului „Limes Dacicus”, Acta Musei Napocensis 5, 75-98.

FERENCZI 1971 
Ferenczi I., Câteva precizări în legătură cu noțiunea de Limes Dacicus, Apulum IX, 599-625.

FERENCZI 1973

Ferenczi I., Contribuții la cunoașterea limes-ului roman la nord de Someșul Mare. Partea I, Sargetia X,79-105.

FERENCZI 1974

Ferenczi I., Investigații noi pe limes-ul de nord și nord-est al Daciei Porolissensis, File de Istorie 3, 181-189.

FERENCZI 1975

Ferenczi I., Limes-ul Daciei Porolissensis între Valea Zagrei și Valea Mureșului, Sargetia XI-XII, 1974-1975 (1975), 285-289.

FERENCZI 1976

Ferenczi I., Contribuții la cunoașterea limes-ului roman de la nord de Someșul Mare. Partea a II-a, File de Istorie 4, 107-133.

FERENCZI 1988

Ferenczi I., Limes-ul Daciei. Sectorul de pe Someșul (Unit). Elemente de apărare pe subsectorul Ileanda-Tihău, Acta Musei Porolissensis XII, 251-289.

FERENCZI 1991

Ferenczi I., Limes-ul Daciei. Sectorul de pe Someșul (unit). Elemente de apărare de pe sub-sectorul Căsei-Ileanda, Acta

FINÁLY 1904 Musei Porolissensis XIV-XV, 1990-1991 (1991), 127-151.

Finály, G., A limes Dacicus és a pugujori földvár, Archaeologiai Ertesitő 24, 1904, 9-15.

FRANZEN/MATEI/MARCU 2007

Franzen, P./Matei, Al. V./Marcu, F., The Roman Fort at Romita (Dacia). Results of the Geophysical Survey, Acta Musei Napocensis 41-42/1, 2004-2005 (2007), 161-177.

GUDEA 1979

Gudea, N., The defensive system of Roman Dacia, Britannia $10,63-87$.

GUDEA 1985

Gudea, N., Contribuții la istoria militară a Daciei Porolissensis I. Linia înaintată de turnuri și fortificații mici de pe sectorul de nord-vest al limesului provinciei între castrele de la Bologa și Tihău, Acta Musei Porolissensis XI, 143-218.

GUDEA 1997

Gudea, N., Der Meseș - Limes. Die vorgeschobene Kleinfestungen auf dem westlichen Abschnitt der Grenze der Provinz Dacia Porolissensis/Limesul de pe Munții Meseș. Linia inaintată de turnuri de pază de pe sectorul de vest al provinciei Dacia Porolissensis (Zalău).

GUDEA 1997

Gudea N., Der Dakische Limes. Materialien zu seiner Geschichte (Mainz: Verlag des Römisch-Germanischen Zentralmuseums Mainz).

\section{GUDEA 2000}

Gudea, N., Noțiunea de limes: frontieră sau concepție de apărare? Câteva reflecții în legătură cu o carte recent apărută, Ephemeris Napocensis IX-X, 1999-2000 (2000), 209-230.

GUDEA/LUCĂCEL 1975

Gudea, N., Lucăcel, Inscripții și monumente sculpturale în Muzeul de Istorie și Artă Zalău (Zalău).

GUDEA/LUCA 2010

Gudea, N., Luca, S. A., Arheologice și Istorie (IV). Descoperiri din județul Sălaj (Oradea).

LĂZĂRESCU/BILAȘCO/VESCAN 2016

Lăzărescu, V.-A./Bilașco, Șt./Vescan, I., Big Brother is watching you! Approaching Roman surveillance and signaling at Porolissum. In: Coriolan H. Opreanu/V.-A. Lăzărescu (eds.), Lanscape Archaeology on the Northern
Frontier of the Roman Empire at Porolissum. An Interdisciplinary Research Project (Cluj-Napoca: Mega), 275-304.

\section{MARCU 2009}

Marcu, F., Organizarea internă a castrelor din Dacia (ClujNapoca).

MARCU/CUPCEA 2013

Marcu, F./Cupcea, G., Topografia limes-ului de nordvest al Daciei în zona castrului de la Bologa. In: S. Forțiu (ed.), Arheovest I. Interdisciplinaritate în arheologie. In memoriam Liviu Măruia (Szeged: JATEPress), 569-589.

\section{MATEI 1996}

Matei, Al. V., Limes Porolissensis-o nouă linie de apărare zid, șanțuri, turnuri-descoperită în fața complexului militar roman de la Porolissum, Acta Musei Porolissensis XX, 63-73.

\section{MATEI 2005}

Matei, Al., V., Apeductele romane pe piloni de la Porolissum. In C. V. Mușețeanu/M. Bărbulescu/D. Benea (eds.), Corona Laurea. Studii în onoarea Luciei Țeposu Marinescu (București: Muzeul National de Istorie a României), 293-311.

\section{MATEI 2007}

Matei, Al. V., O nouă poartă amenajată în zidul provinciei Dacia descoperită în fața complexului militar de la Porolissum. In S. Nemeti/F. Fodorean/E. Nemeth/S. Cociş/ Irina Nemeti, Mariana Pîslaru (eds.), Dacia Felix. Studia Michaeli Bărbulescu oblata, Dacia Felix. Studia Michaeli Bărbulescu Oblata (Cluj-Napoca: Tribuna), 250-269.

MATEI/LAKO 1979

Matei, Al. V./Lako, E., Repertoriul descoperirilor și așezărilor de epocă romană pe teritoriul județului Sălaj, Acta Musei Porolissensis III, 121-135.

\section{MOGA 1950}

Moga, M., Traiul populației daco-romane și barbare la granița de vest a Daciei. Activitatea șantierului archeologic Porolissum, Studii Clasice și Istorie Veche 1, 131-135.

MOGA 1985

Moga, V., Din istoria militară a Daciei Romane: Legiunea XIII Gemina (Cluj-Napoca: Dacia)

OPREANU/LĂZĂRESCU/ȘTEFAN 2013

Opreanu, C. H./Lăzărescu, V.-A./Ștefan, D., Noi cercetări la Porolissum, Analele Banatului 21, 83-106.

OPREANU/LĂZĂRESCU/ȘTEFAN 2013A

Opreanu, C. H./Lăzărescu, V.-A./Ștefan, D., Recent Geophysical Surveys at Porolissum. In: Arheovest I. Interdisciplinaritate în arheologie. In memoriam Liviu Măruia (Szeged: JATEPress), 509-524.

OPREANU et alii 2014

Opreanu, C. H./Lăzărescu, V.-A./Roman, A./Ursu, T., New Light on a Roman Fort Based on a LiDAR Survey in the Forested Landscape from Porolissum, Ephemeris Napocensis, 24, 71-86.

PISO 2000

Piso, I., Les légions dans les provinces de Dacie, In: Yann Le Bohec (ed), Les légions de Rome sous le Haut-Empire. Actes du congrès de Lyon, Collection du Centre d'Etudes Romaines et Gallo-Romaines (Paris: Diffusion De Boccard), 205-225.

\section{PISO 2005}

Piso, I., An der Nordgrenze des Römischen Reiches, Ausgewählte Studien (Stuttgart: Franz Steiner Verlag).

PISO/DEAC 2016

Piso, I., Deac, D., Inscriptiones Daciae Romanae. Appendix I. Inscriptiones laterum Musei Zilahensis (Cluj-Napoca: Mega)

PROTASE 1960

Protase, D., Castrul auxiliar de la Tihău, Materiale și Cercetări arheologice 7, 384-385.

PROTASE 1994 
Protase, D., Castrul roman de la Tihău, Ephemeris Napocensis IV, 75-102.

PROTASE 1995

Protase, D., Orizonturi Daco-Romane (Cluj-Napoca: Carpatica).

RADNÓTI 1945

Radnóti, A., A dáciai limes a Meszesen, Archaeologiai Ertesitő 4-5, 1944-1945 (1945), 137-168.

RITTERLING 1925

Ritterling, E., Rheinische Legionare an der underen Donau, Germania 9, 1925, 141-145.

ROMAN et alii 2016

Roman, A./Ursu, T.-M./Lăzărescu, V.-A./Opreanu, C. H., Multi-sensor surveys for the interdisciplinary landscape analysis and archaeological features detection at Porolissum. In: Coriolan H. Opreanu/V.-A. Lăzărescu (eds.), Lanscape Archaeology on the Northern Frontier of the Roman Empire at Porolissum. An Interdisciplinary Research Project (Cluj-Napoca : Mega), 237-262.

SCURTU 1997

Scurtu, E., F., "Radiografia” geofizică a unei părți a orașului roman Porolissum, Studii și Cercetări de Istorie Veche și Arheologie 48, 4, 361-372.

SCURTU 2003

Scurtu, E., F., Raport preliminar în legătură cu cercetările arheologice de la Porolissum: cercetări geofizice, Acta Musei Porolissensis 25, 257-259.

\section{TEODOR 2016}

Teodor, E., S., De pază pe Limes Transalutanus. Despre turnurile de pe segmentul sudic. In: E. Teodor (ed.), Arheologia peisajului și frontierele romane (Târgoviște: Cetatea de Scaun), 67-96

TORMA 1880

Torma, K., A limes Dacicus felső resze (Budapest 1880).

\section{TÉGLÁS 1906}

Téglás, G., A német birodalmi limes-bizottság eredményei és kutatásainak tanulságái hazai limestanulmányok rendszeresitése szempont jából, Magyar Tudomanyos Akademiavévkönyvei, 1906, 393-410.

TÉGLÁS 1907

Téglás, G., A limes dacicus igazolása, Magyar Tudomanyos Akademiavévkönyvei, 1907 565-580.

\section{WHITTAKER 1994}

Whittaker, Ch., Frontiers of the Roman Empire. A Social and Economic Study (Baltimore: Johns Hopkins University Press).

\section{WOLLMANN/BOT 1974}

Wollmann, Gh., Bot, Gh., Despre castrul și garnizoana romana de la Tihău, In: H. Daicoviciu (ed.), In Memoriam Constantini Daicoviciu, (Cluj-Napoca). 


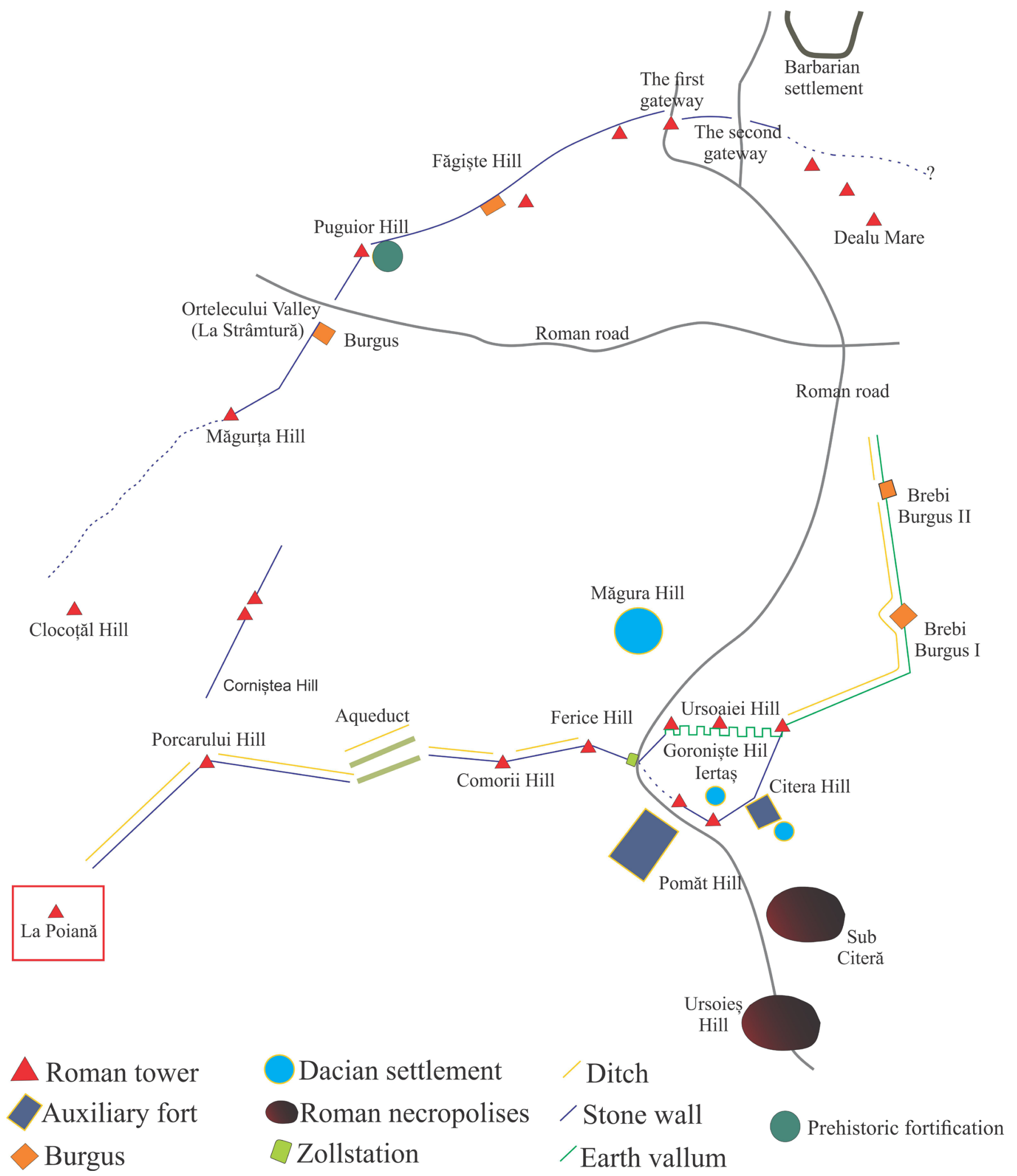

Plate I. The watchtower from Poiana Moigrădanilor / La Maje it its frontier landscape settings (redrawn after MATEI 2007, 259). 
Studies

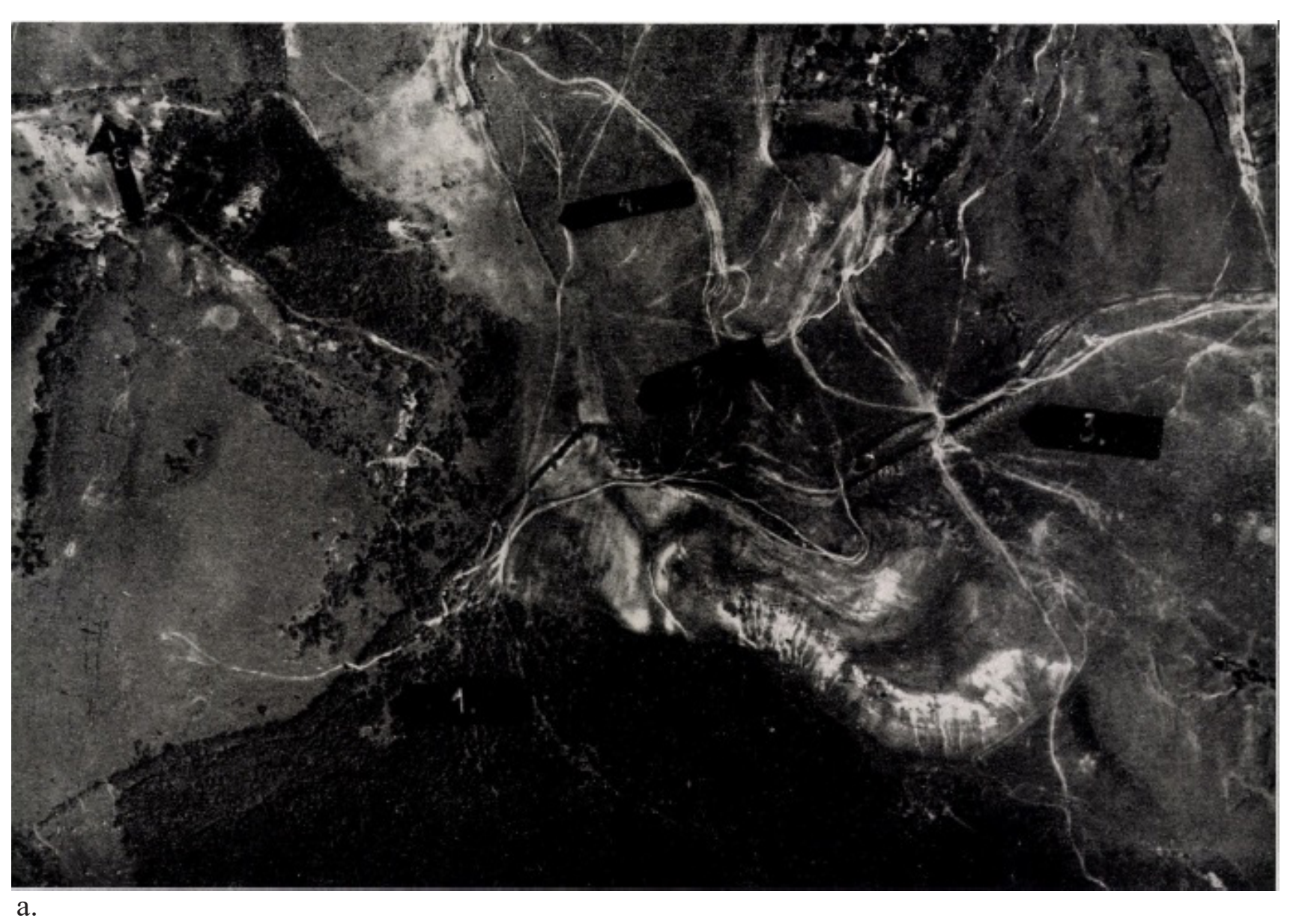

a.

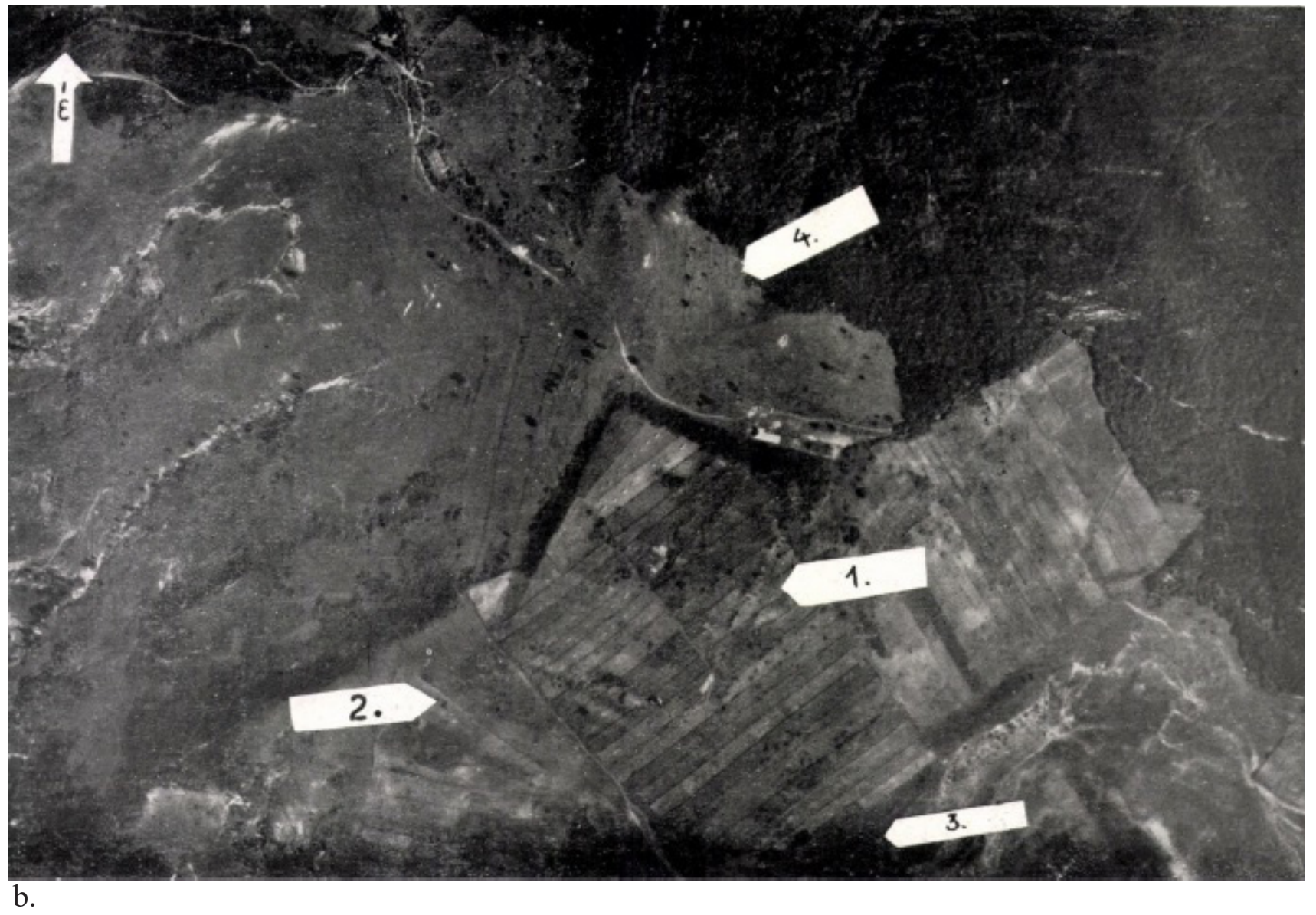

b.

Plate II. Aerial photos made by Radnóti A; a-the watchtower from Poiana Moigrădanilor, the linear fortifications and the aqueductus, b-the

auxiliary fort from Porolissum-Pomet (after RADNÓTI 1945, LXVI/2. LXVII/2)

\section{(1)

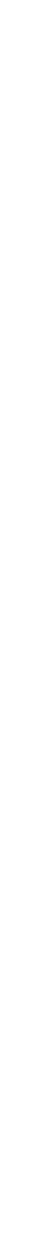

2 Journal of Ancient History and Archaeology No.6.1/2019 

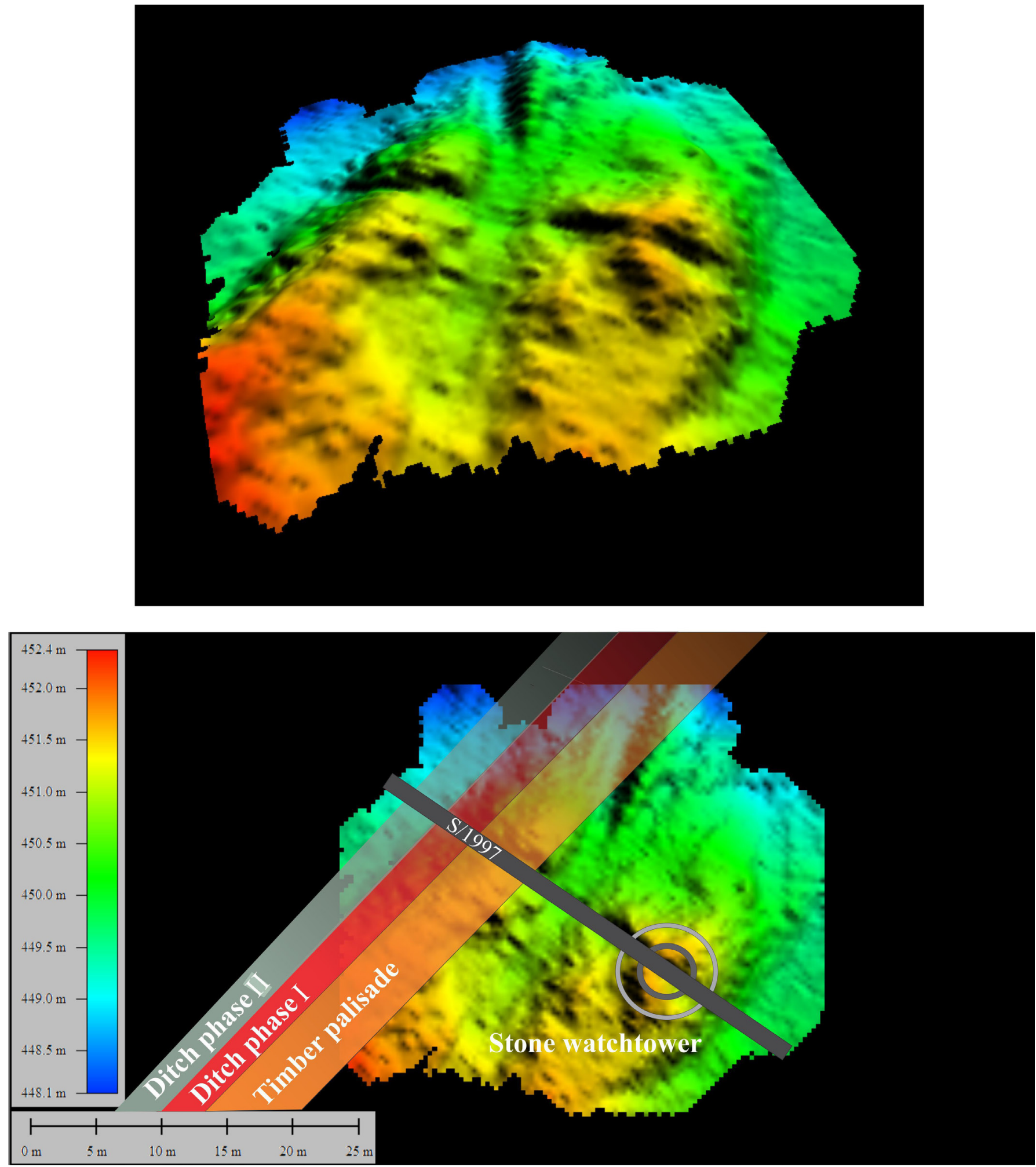

Plate III. DTM resulted from topographic survey overlapped by the archaeological features and the 1997 georeferenced trench. 


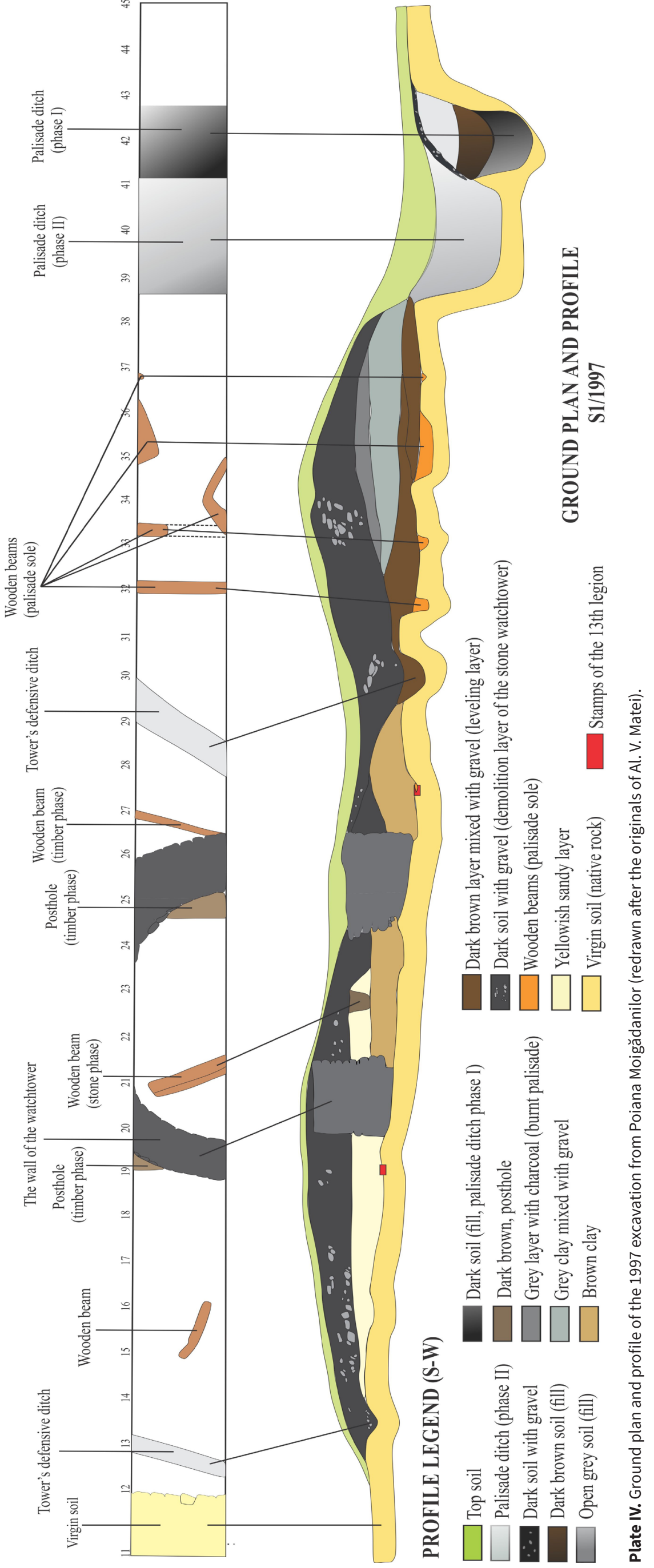

54 Journal ofAncient History and Archaeology No.6.1/2019 


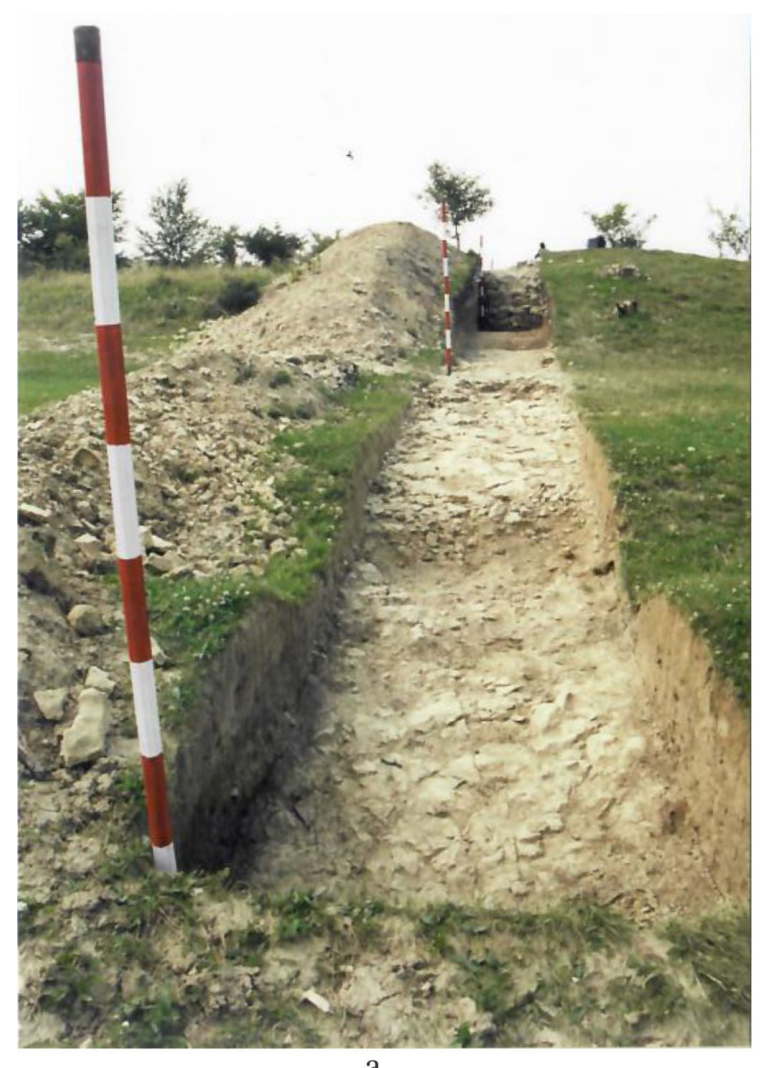

a

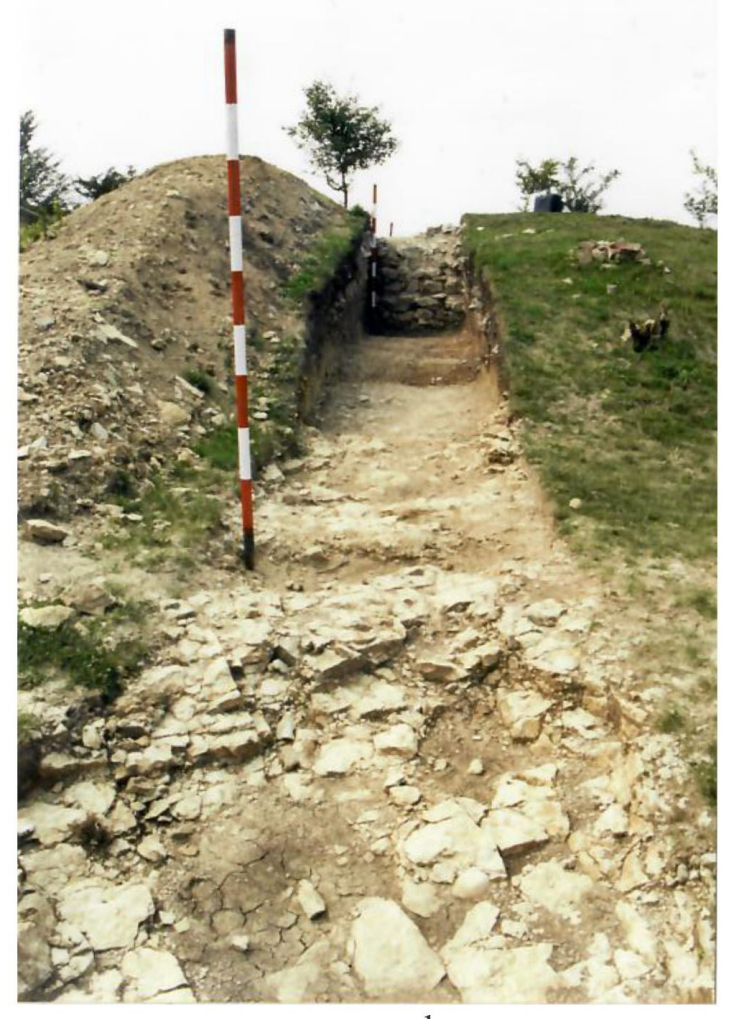

b
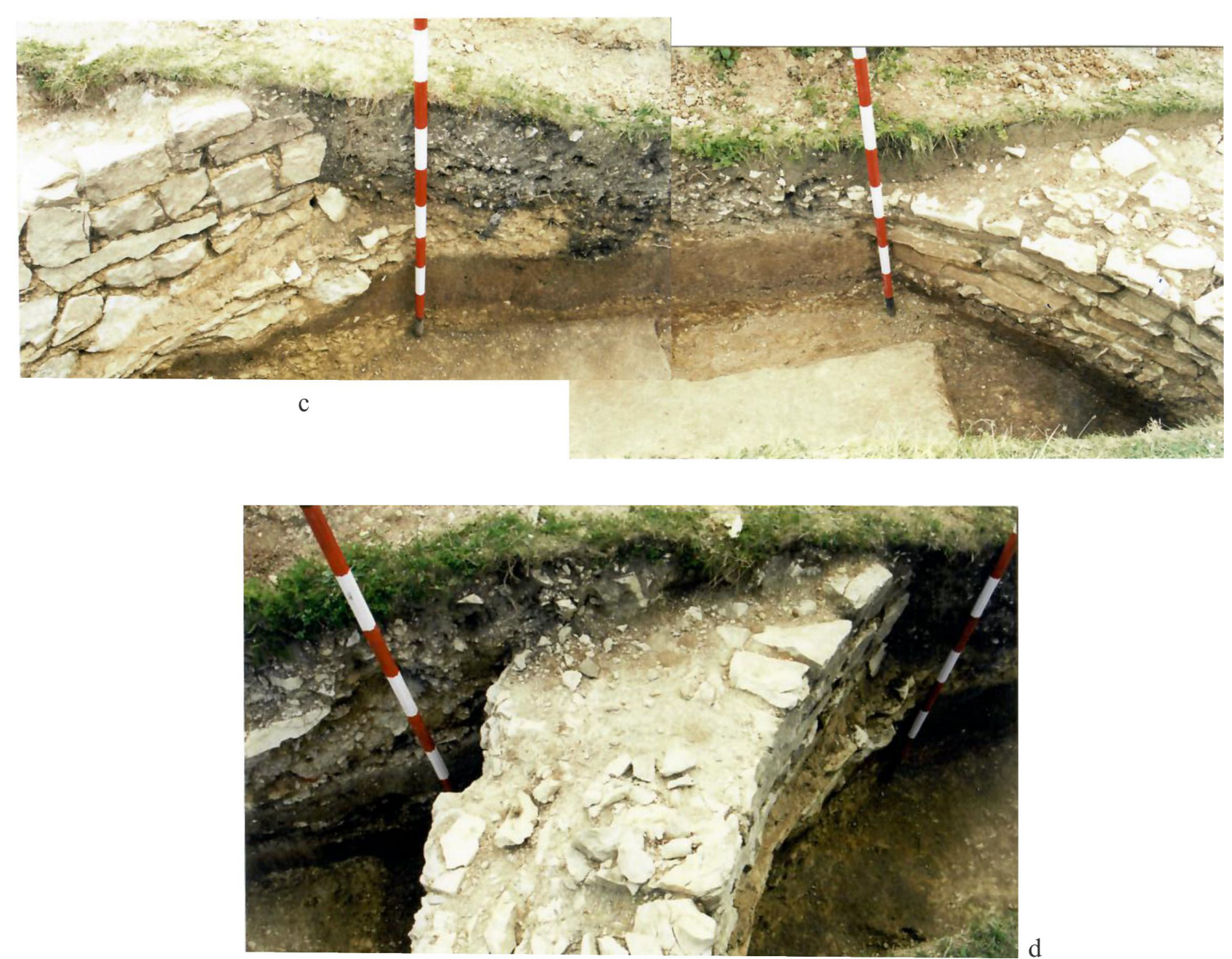

Plate V. Photos of the excavation: a-b, general view of the trench from East; $c$, stratigraphy inside the watchtower; $d$, the wall of the watchtower, Est (photos by Al. V. Matei, @ Zalău County Museum of History and Art). 


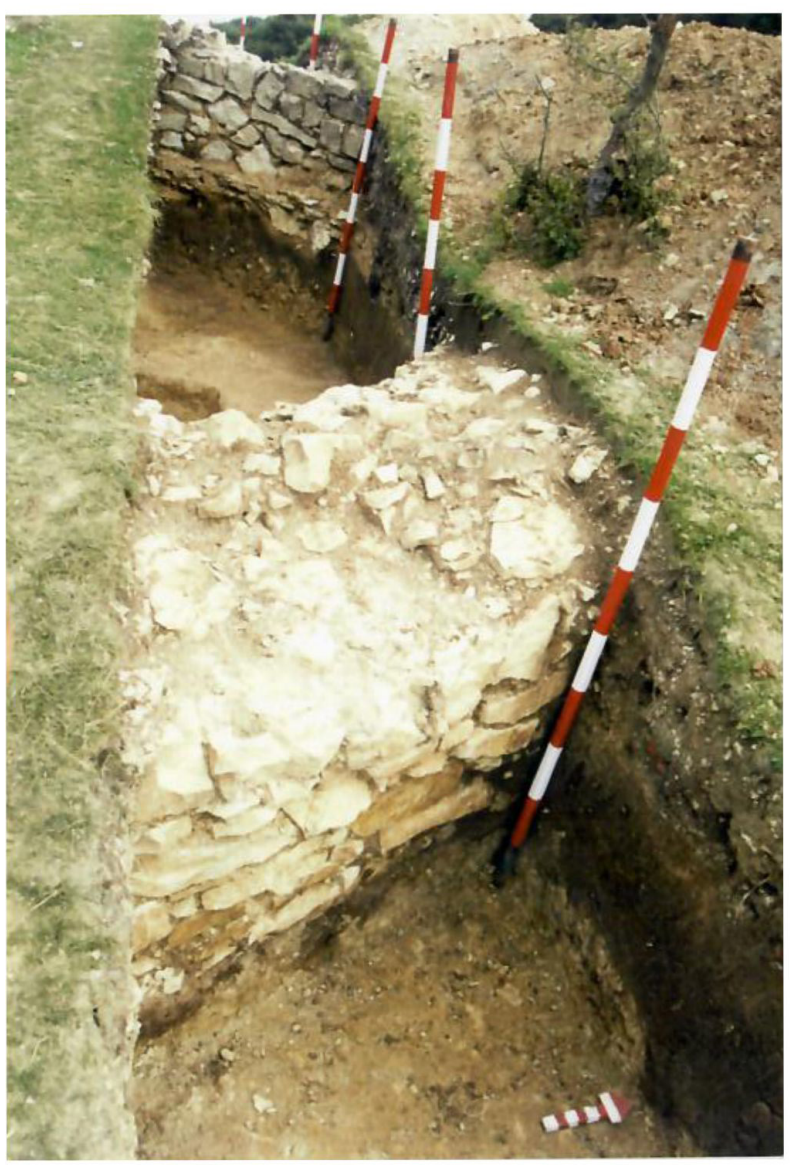

a

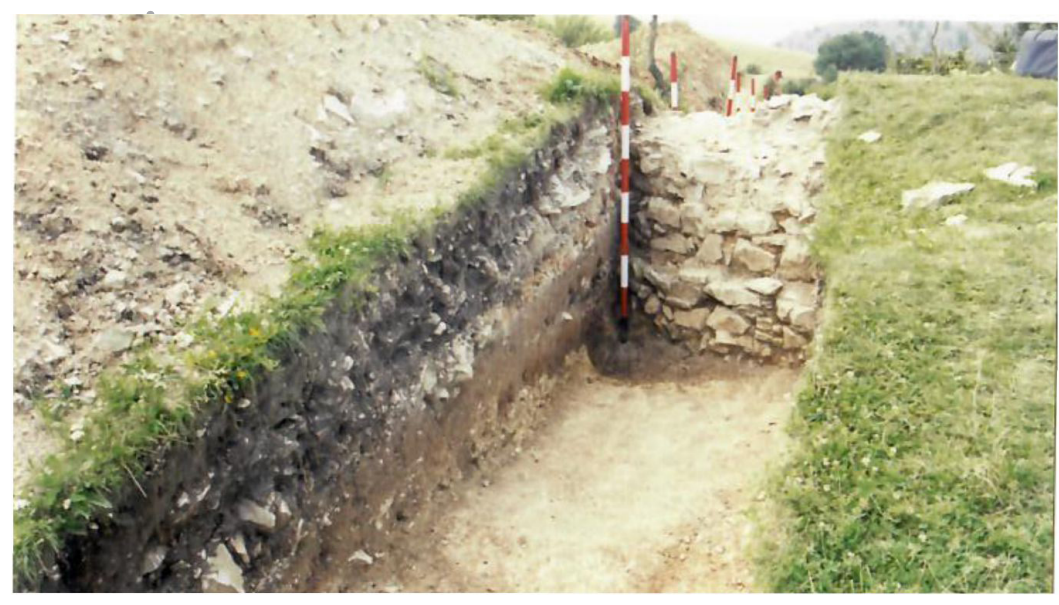

b

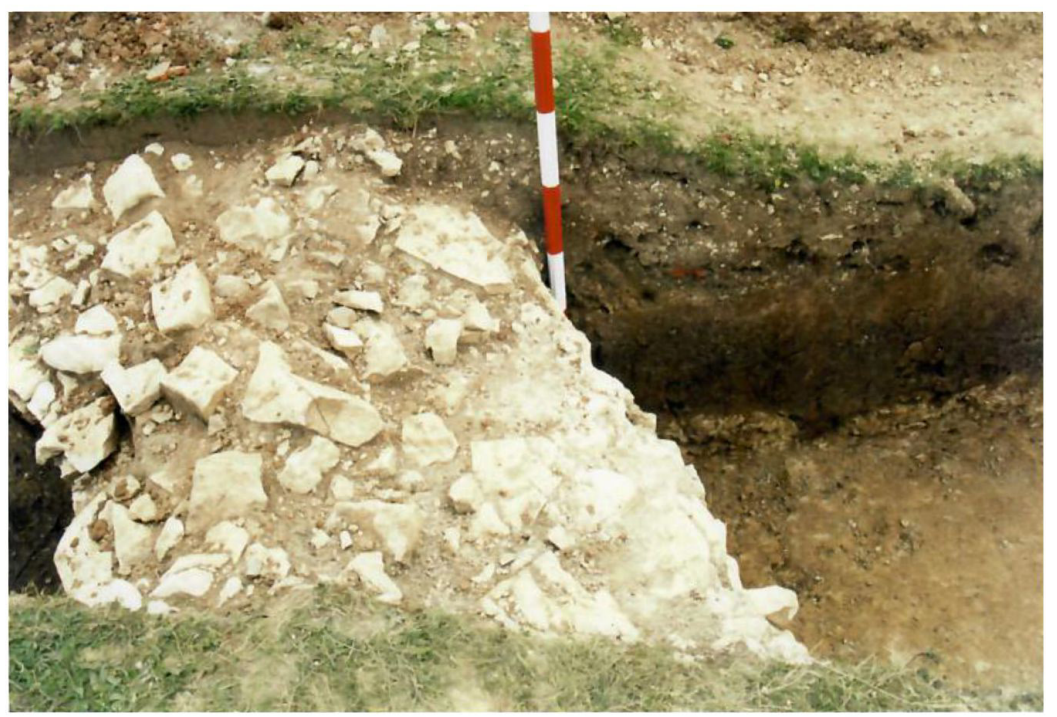

$\mathrm{c}$

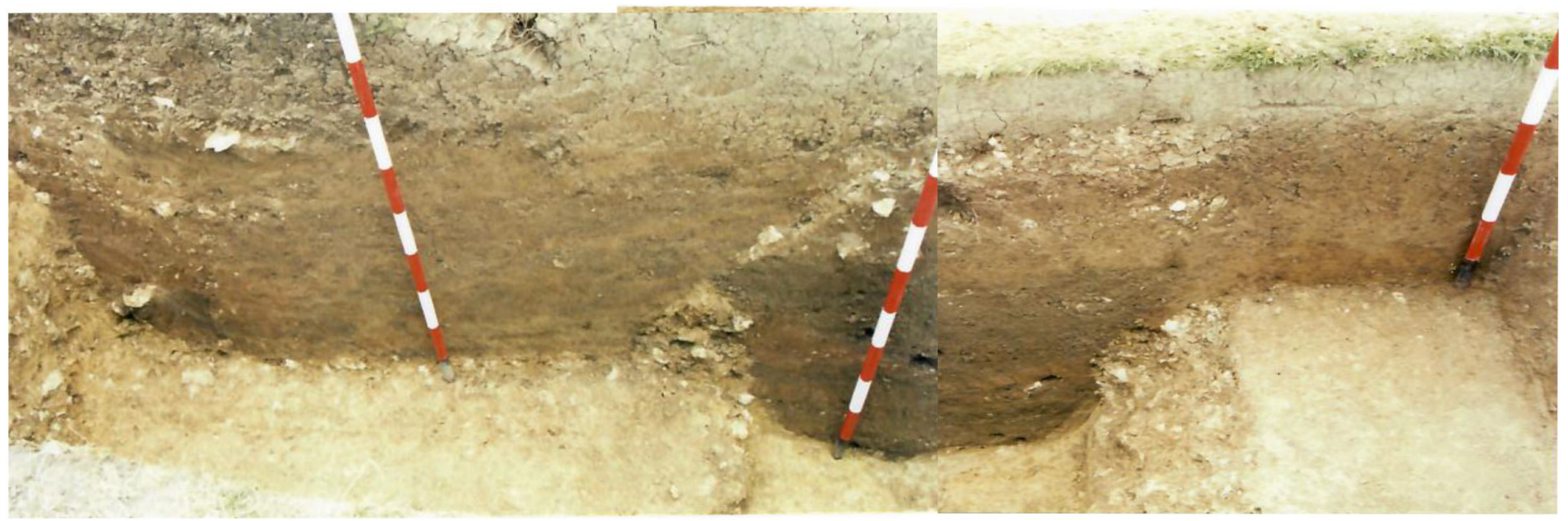

d

Plate VI. Photos of the excavation: a-c, the walls of the watchtower; d. the palisade ditches (photos by Al. V. Matei, @ Zalău County Museum of History and Art). 


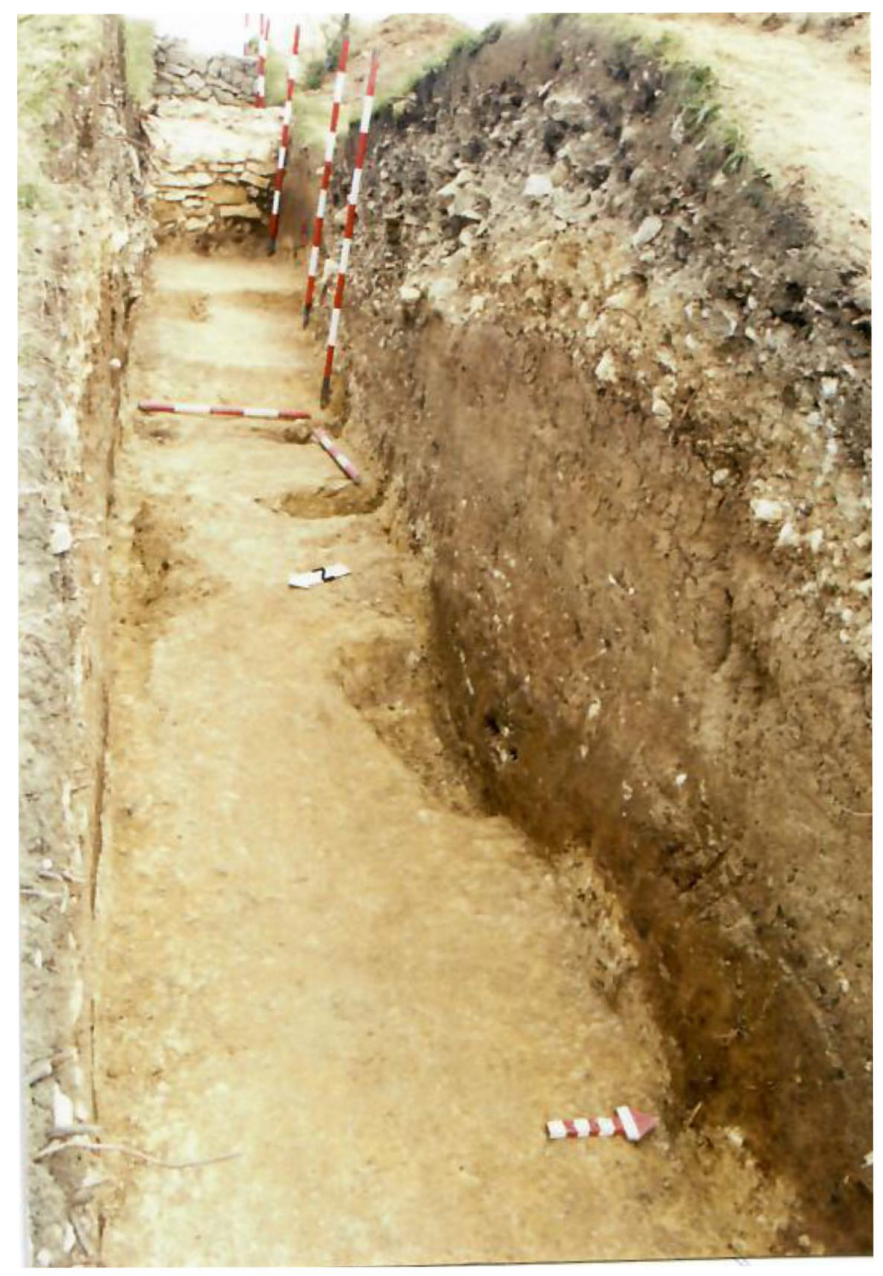

a

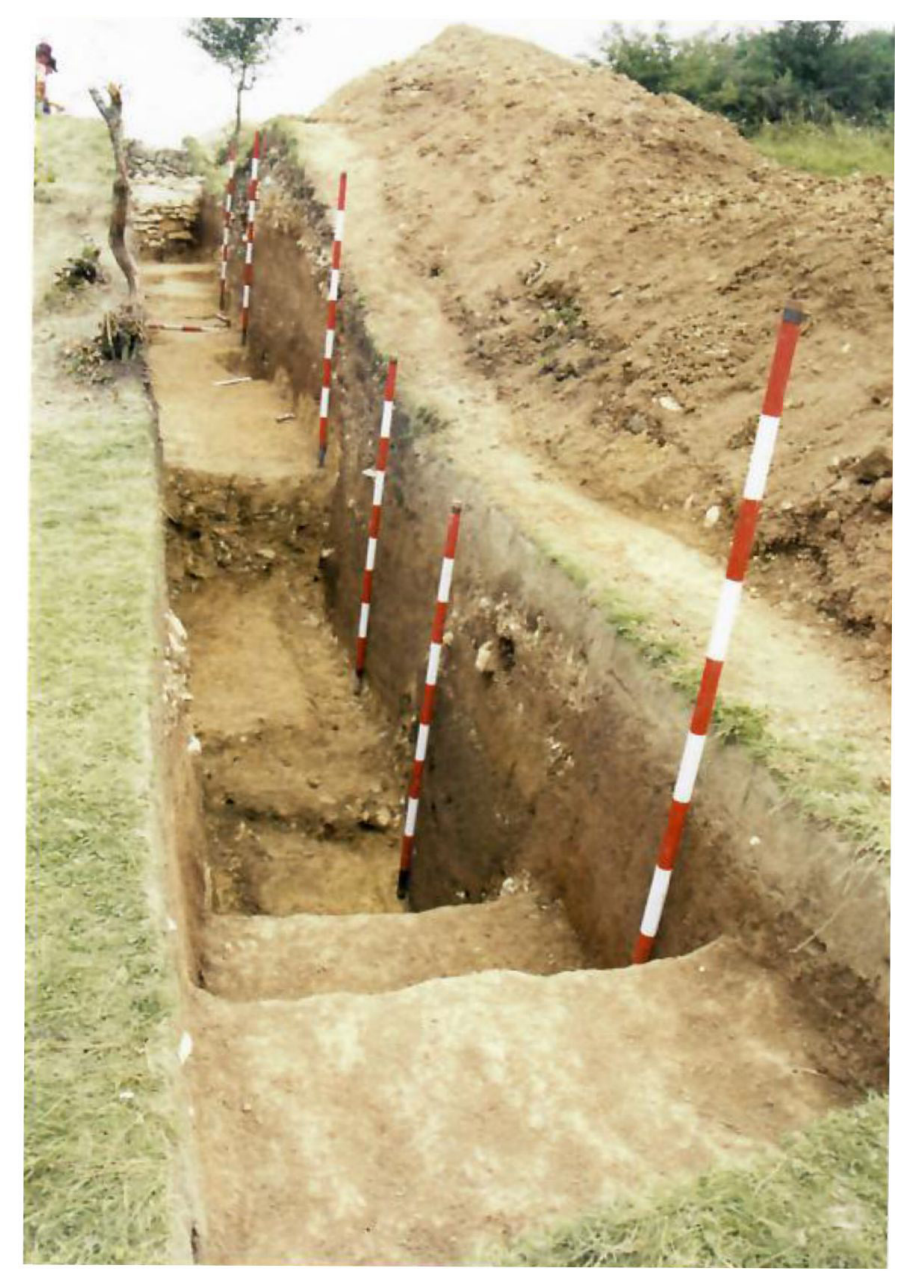

b

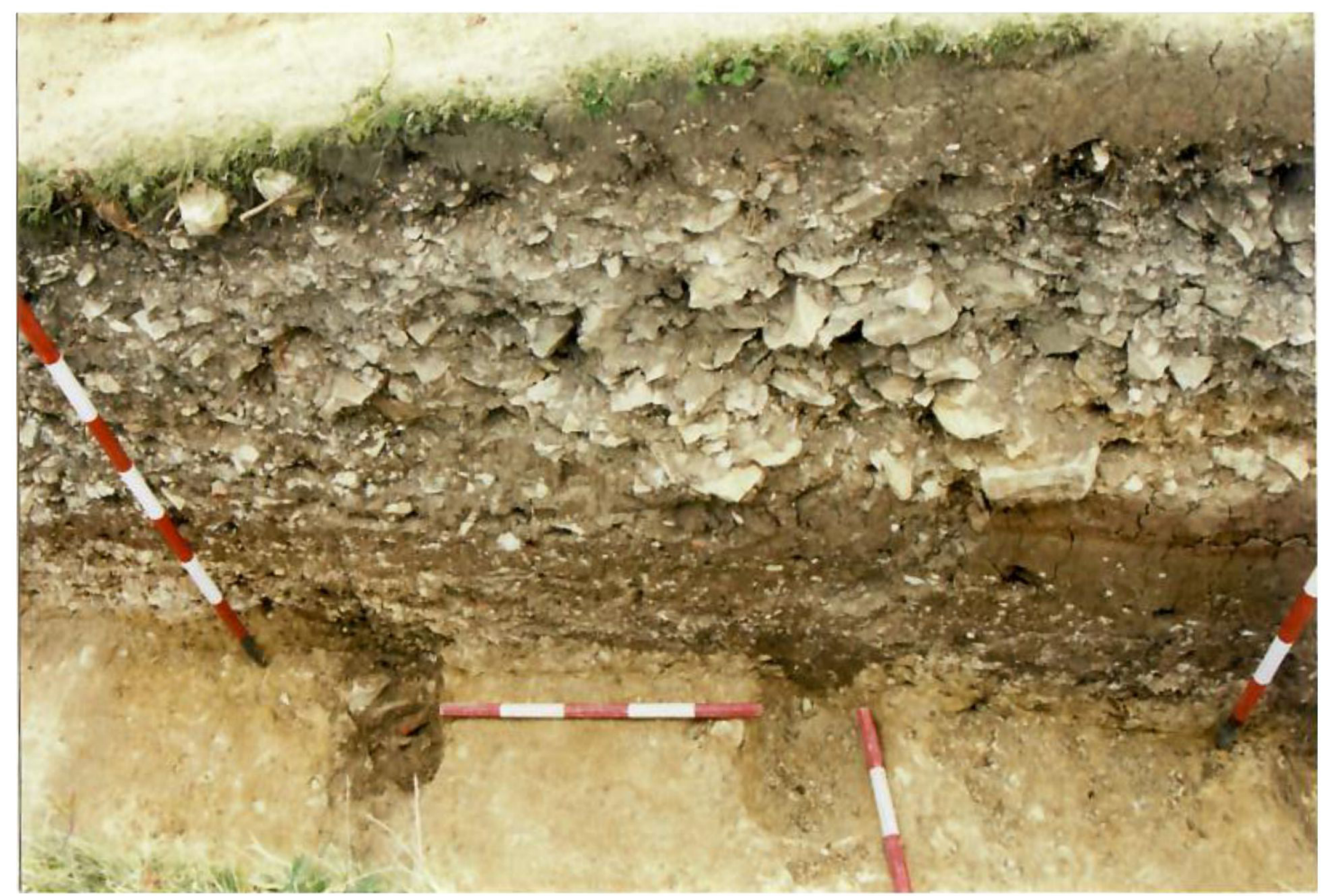

c

Plate VII. Photos of the excavation: a-c, the palisade (photos by Al. V. Matei, ๑ Zalău County Museum of History and Art). 

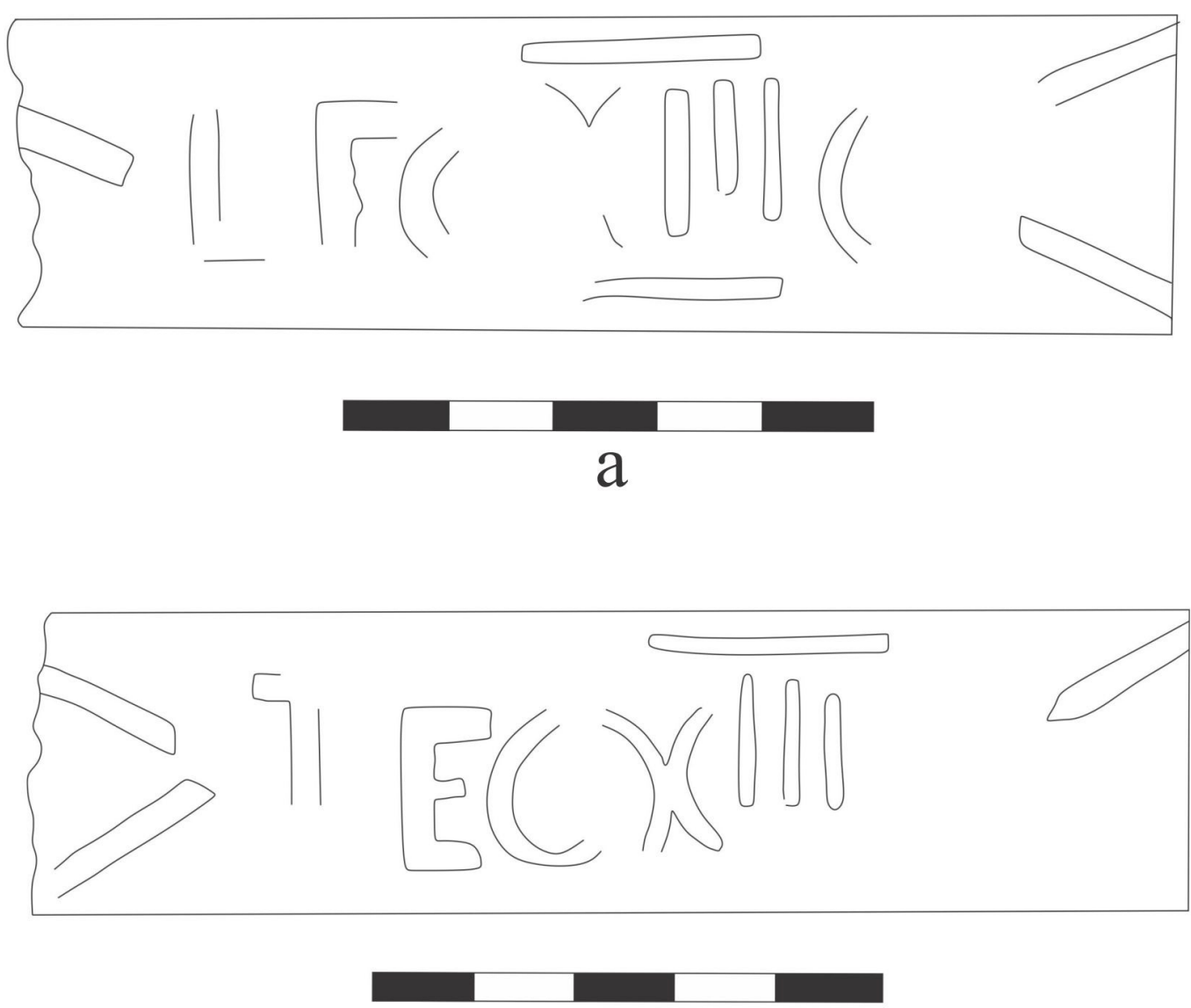

b
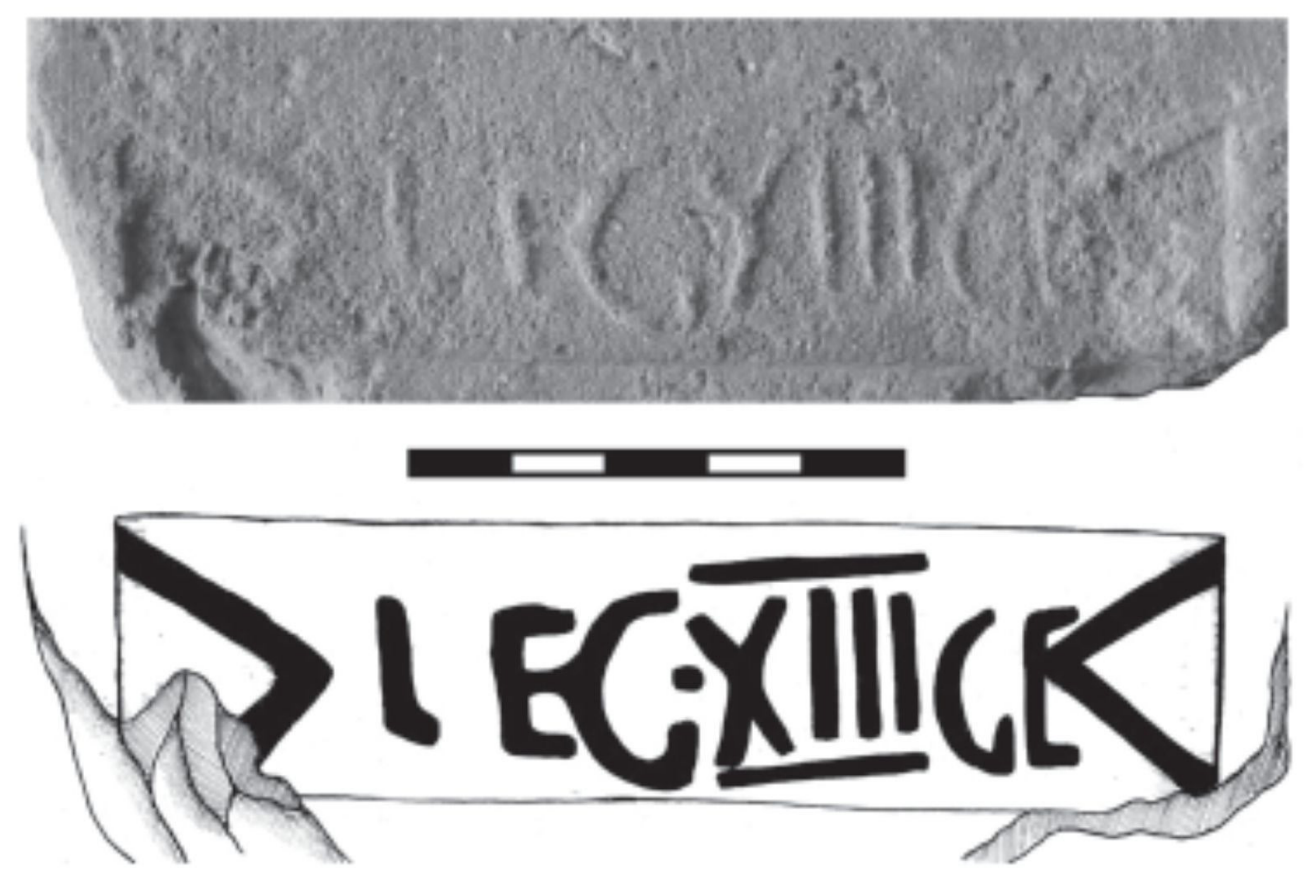

C

Plate VIII. a-b: the stamps discovered within the watchtower from Poiana Moigrădanilor (redrawn after the originals); c: analogy from Porolissum (after PISO/DEAC 2016, 32). 


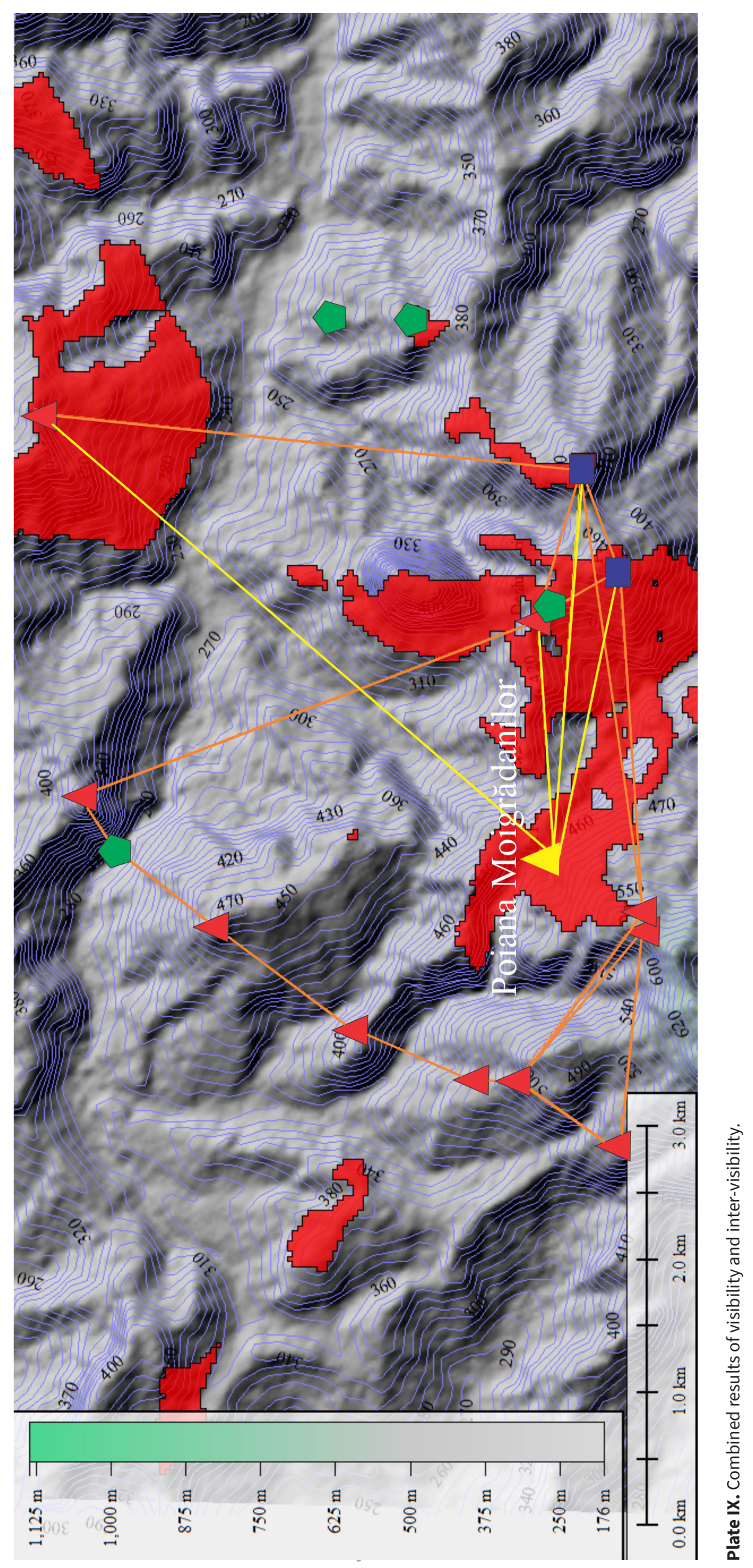

